\title{
Kinetic and thermodynamic aspects of arsenic (III) adsorption onto iron oxide obtained from iron oxalate
}

\author{
A. Negrea, M. Ciopec, L. Lupa, C. Muntean, R. Lazau \\ \& P. Negrea \\ University Politehnica Timisoara, Faculty of Industrial Chemistry and \\ Environmental Engineering, Romania
}

\begin{abstract}
Drinking water has been identified as one of the major sources of arsenic exposure by the general population. A variety of treatment processes has been studied for arsenic removal from water. One of the most used methods is adsorption. The most efficient adsorbent materials are those with iron content considering the affinity of arsenic towards iron. Relatively limited information is available regarding the impact of temperature on the arsenic (As) (III) adsorption kinetic and equilibrium capacities on iron oxide. In this paper we studied the possibility of using iron oxide as an adsorbent for the removal of As (III) from aqueous solutions. The iron oxide was obtained through annealing of iron oxalate at $550^{\circ} \mathrm{C}$. The effects of contact time, initial concentration of the solutions and temperature on the removal of As (III) were investigated in order to explain the adsorption mechanism. The kinetic of As (III) adsorption can be described well by the pseudo-second-order models. The equilibrium adsorption data were fitted using Freundlich and Langmuir isotherm equations and the corresponding parameters were calculated and discussed in detail. An increase in temperature increases the values of the overall adsorption reaction rate constant. An examination of thermodynamic parameters shows that the adsorption of As (III) by iron oxide is an endothermic process and is spontaneous at the specific temperature investigated.
\end{abstract}

Keywords: arsenic, adsorption, iron oxide, kinetic, thermodynamic. 


\section{Introduction}

Water is essential for sustaining human, animal and plant life. Drinking water contains many trace contaminants, both cationic and anionic [1]. Among common inorganic pollutants, the arsenic (As) has been largely studied because of its potential harmfulness to human health [2]. Background arsenic concentrations in natural water are low, but elevated arsenic concentration are common in groundwater as a result of natural conditions (volcanic emission, minerals) or anthropogenic impacts (mining activities, combustion of fossil fuels and the use of arsenic pesticides) [3-5].

Literature survey reveals that there are a good number of approaches for arsenic remediation from drinking water. Amongst the various methods like oxidation-reduction, precipitation, co precipitation, sorption, electrolysis and cementation, solvent extraction, ion exchange, ion flotation and bioremediation [5-8] proposed to negotiate the problem of arsenic contamination in drinking water, sorption technique is, however, the most common and is considered to be an effective method.

Sorbents of different types like biomaterials [2, 7, 9], metal oxide/hydroxide $[3,6,10-14]$, zeolite [5], activated carbon [5, 16], laterite [17] etc have been used by workers to achieve the goal. Iron oxides are present in the environment as a wide range of minerals. These are the most important adsorbents for arsenic removal from drinking water because of their abundance and strong affinity, and both arsenite and arsenate show a high affinity for the iron oxide surface [10-14, 16-20].

The objective of our research were to gain an understanding of the adsorption process kinetics and to describe and explain some important thermodynamic parameters for the arsenic removal process from water when we used as adsorbent an iron oxide obtained from iron oxalate.

\section{Experimental}

\subsection{Sorbent characterization}

The sorbent for this study was obtained trough annealing of the iron oxalate $\left(\mathrm{Fe}(\mathrm{COO})_{2} \cdot 2 \mathrm{H}_{2} \mathrm{O}\right)$ at $550^{\circ} \mathrm{C}$. For the resulted product, iron oxide $\left(\mathrm{Fe}_{2} \mathrm{O}_{3}\right)$ was determined the specific surface area and the acid base properties.

The specific surface of the sample was measured using a Micrometrics ASAP 2020 BET surface area analyzer, by cold nitrogen adsorption.

Colloidal chemical properties of aqueous dispersions of various solids represents a subject of intensive research. The dispersion behavior is dictated by interfacial chemistry of solids and suspending media. The particles of these solids in aqueous solutions develop their surface charge through acid-base surface reactions. The point of zero charge, $\mathrm{pH}_{\mathrm{pzc}}$, and the number of acidic and basic groups on these materials surfaces are important guides to interfacial properties $[5,13,15,21]$. 
The point of zero charge of the iron oxide was determined by the batch equilibration technique. Samples of iron oxide $(0.2 \mathrm{~g})$ have been treated with 100 $\mathrm{mL} \mathrm{NaCl}$ solution $\left(0.01,0.005\right.$ and $\left.0.001 \mathrm{~mol} \mathrm{~L}^{-1}\right)$ of various $\mathrm{pH}$ values, in the $\mathrm{pH}$ range from 2 to 12 . The suspensions have been stirred with $400 \mathrm{rpm}$ and left for equilibration $24 \mathrm{~h}$ at room temperature. The initial $\mathrm{pH}$ values $\left(\mathrm{pH}_{\mathrm{i}}\right)$ have been adjusted by adding a small amount of $\mathrm{HNO}_{3}$ or $\mathrm{NaOH}$ solution (concentration 0.1 or $2 \mathrm{~mol} \mathrm{~L}^{-1}$, so that the volume variation was minimal). The role of the background electrolyte $\mathrm{NaCl}$ was to keep the ionic strength constant. All used chemicals were in analytical reagent grade. The $\mathrm{pH}$ values have been measured using a "CRISON MultiMeter MM41" pH-meter.

\subsection{Batch experiments}

In the first instance the effect of contact time was studied at different temperature $(291,295,313 \mathrm{~K})$. In each experiment, $0.1 \mathrm{~g}$ of sorbent was suspended in 100 $\mathrm{mL}$ of $100 \mu \mathrm{g} / \mathrm{L}$ solution of As (III). The samples were stirred using agitating device with glass rod (stirring speed $200 \mathrm{rpm})$ at different stirring times $(15,30$, $45,60,90,120$ and 150 minutes). The temperature of the sample was kept using a CRISON MultiMeter MM41 apparatus. After stirring the samples were centrifuged at $1200 \mathrm{rpm}$ for $30 \mathrm{~min}$ using a ROTINA 420 centrifuge. Arsenic concentration in the supernatants was measured trough atomic adsorption spectrometry with hydride generation using a spectrophotometer VARIAN SpectrAA 110 with hydride generation VGA 77.

Similar batch experiments were performed to study the influence of the initial As (III) concentration $(100,200,300,400,500,600$ and $700 \mu \mathrm{g} / \mathrm{L})$. The initial $\mathrm{pH}$ of the solutions was kept around the value 7, which was at the middle of the plateau corresponding to the plot of $\mathrm{pH}_{\mathrm{f}}$ versus $\mathrm{pH}_{\mathrm{i}}$ who gives the $\mathrm{pH}_{\mathrm{pzc}}$ and which also represent the most common $\mathrm{pH}$ value found in the natural waters. The $\mathrm{pH}$ of the solutions was measured using a multi parameter instrument WTW Multi 197i.

The equilibrium adsorption capacity was calculated using the following equation:

$$
\mathrm{q}_{\mathrm{e}}=\left(\mathrm{C}_{0}-\mathrm{C}_{\mathrm{e}}\right) \frac{\mathrm{v}}{\mathrm{m}}
$$

where: $\mathrm{C}_{0}$ - initial concentration of arsenic in solution, $\mu \mathrm{g} / \mathrm{L}$;

$\mathrm{C}_{\mathrm{e}}$ - equilibrium concentration of arsenic in solution, $\mu \mathrm{g} / \mathrm{L}$;

$\mathrm{v}$ - solution volume, $\mathrm{L}$;

$\mathrm{m}$ - amount of the absorbent, $\mathrm{g}$.

\section{Results and discussion}

\subsection{Sorbent properties}

Figure 1 illustrates the representation for the determination of $\mathrm{pH}_{\mathrm{pzc}}$. The plateau corresponding to the plot of final $\mathrm{pH}$ values of the suspensions $\left(\mathrm{pH}_{\mathrm{f}}\right)$ against the 
initial values $\left(\mathrm{pH}_{\mathrm{i}}\right)$ gives the value of $\mathrm{pH}_{\mathrm{pzc}}$. The presence of this plateau shows that the material presents amphoteric properties, and acts as a buffer. The plateau of the $\mathrm{pH}_{\mathrm{i}}-\mathrm{pH}_{\mathrm{f}}$ plot corresponds to the $\mathrm{pH}$ range where the buffering effect of the iron oxide surface takes place, i.e. where for all $\mathrm{pH}_{\mathrm{i}}$ in this range the $\mathrm{pH}_{\mathrm{f}}$ is almost the same and corresponds to $\mathrm{pH}_{\mathrm{pzc}}$.

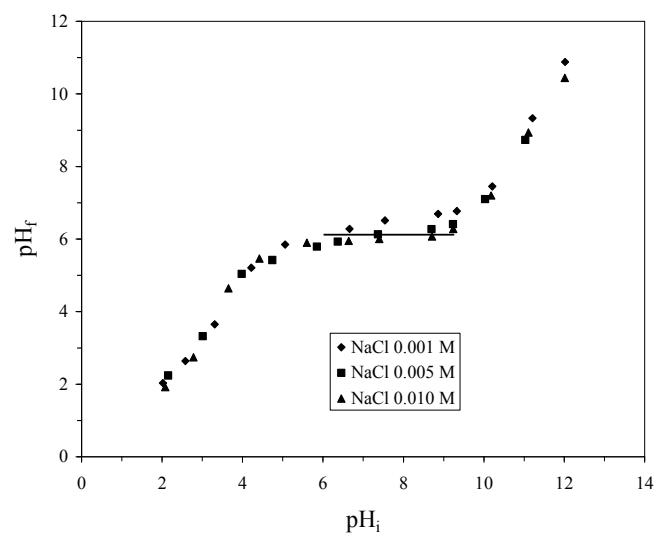

Figure 1: The plot of final solution $\mathrm{pH}\left(\mathrm{pH}_{\mathrm{f}}\right)$ versus initial solution $\mathrm{pH}\left(\mathrm{pH}_{\mathrm{f}}\right)$.

The $\mathrm{pH}$ region where the iron oxide buffers the solution is from $\sim 6$ to $\sim 9.5$. It means that for all values of $\mathrm{pH}_{\mathrm{i}}$, in this range, the $\mathrm{pH}_{\mathrm{f}}$ is the same and equal to $\mathrm{pH}_{\mathrm{pzc}}$. The $\mathrm{pH}_{\mathrm{pzc}}$ determined in 0.005 and $0.01 \mathrm{M} \mathrm{NaCl}$ solutions is practically the same. This leads to the conclusion that $\mathrm{pH}_{\mathrm{pzc}}$ is independent of the ionic strength of $\mathrm{NaCl}$ solutions, i.e. that $\mathrm{NaCl}$ is an indifferent electrolyte. In the case of $0.001 \mathrm{M} \mathrm{NaCl}$ solution one may notice that in the $\mathrm{pH}$ range where the plateau should be, the $\mathrm{pH}_{\mathrm{f}}$ values are somehow higher than the values for the other two $\mathrm{NaCl}$ solutions and are also slightly increasing. This may be due to the fact that the $0.001 \mathrm{M} \mathrm{NaCl}$ solution is too diluted to ensure a constant ionic strength. Therefore we considered as $\mathrm{pH}_{\mathrm{pzc}}$ the value $\sim 6.1$ given by the other two solutions (table 1). One may also notice that in the $\mathrm{pH}$ range $\sim 4.5$ to $\sim 6$ the iron oxide tends to act as a buffer but the buffering effect is incomplete and the $\mathrm{pH}_{\mathrm{f}}$ values remain under the plateau. The $\mathrm{pH}_{\mathrm{pzc}}$ value suggests that the surface of the material should be predominantly positive at $\mathrm{pH}$ values lower than 6.1 and negative at $\mathrm{pH}$ values higher than 6.1 . The surface charge density of the material should increase or decrease with the decrease or increase of the $\mathrm{pH}$ value from the $\mathrm{pH}_{\mathrm{pzc}}$.

Table 1: $\quad$ Some characteristic properties of iron oxide.

\begin{tabular}{|c|c|c|}
\hline Parameter & $\mathrm{pH}_{\mathrm{pzc}}$ & $\mathrm{S}_{\mathrm{BET}}, \mathrm{m}^{2} / \mathrm{g}$ \\
\hline Value & 6.1 & 14.6 \\
\hline
\end{tabular}




\subsection{Kinetic studies}

To attain the adsorption equilibrium time the results of the effect of stirring time on the adsorption capacity of the iron oxide in the process of As (III) removal from water for all the studied temperatures are presented in figure 2 .

As can be seen the equilibrium times lie in the range of $90-120$ minutes at all of studied temperature. The absorbed amount of As (III) ions slightly increase when increasing temperature from 291 to $313 \mathrm{~K}$. For subsequent experiments, an equilibration time of 90 minutes was chosen for the sake of convenience.

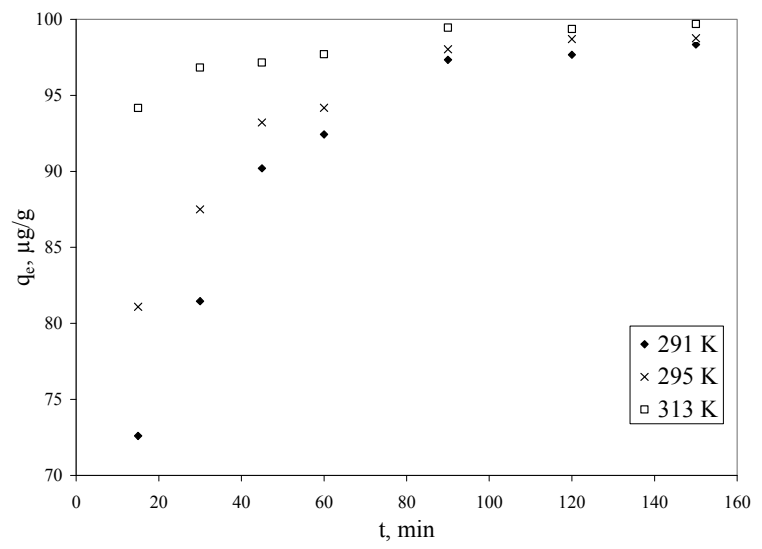

Figure 2: The effect of stirring time on arsenic adsorption capacity of iron oxide at different temperatures.

In order to express the kinetics of arsenic adsorption onto iron oxide the results were analysed using the following models.

The pseudo-first-order kinetic model based on the solid capacity and proposed by Lagergren can be used to determine the rate constant for the adsorption process and the integrated form is expressed by the following equation:

$$
\ln \left(\mathrm{q}_{\mathrm{e}}-\mathrm{q}_{\mathrm{t}}\right)=\ln \mathrm{q}_{\mathrm{e}}-\mathrm{k}_{1} \mathrm{t}
$$

where: $\mathrm{q}_{\mathrm{t}}$ and $\mathrm{q}_{\mathrm{e}}$ represent the amounts of the arsenic adsorbed on the iron oxide at time $\mathrm{t}$ and at equilibrium time, respectively, $\mu \mathrm{g} / \mathrm{g}$;

$\mathrm{k}_{1}$ is the specific adsorption rate constant, $\mathrm{min}^{-1}$.

Figure 3 display the plots of $\ln \left(\mathrm{q}_{\mathrm{e}}-\mathrm{q}_{\mathrm{t}}\right)$ versus $\mathrm{t}$ for As (III) adsorption onto iron oxide for all studied temperatures. The slopes and intercept of the plots are used to estimate the pseudo-first-order rate constant $\left(\mathrm{k}_{1}\right)$ and the equilibrium adsorption capacity $\left(\mathrm{q}_{\mathrm{e}}\right)$, respectively. 


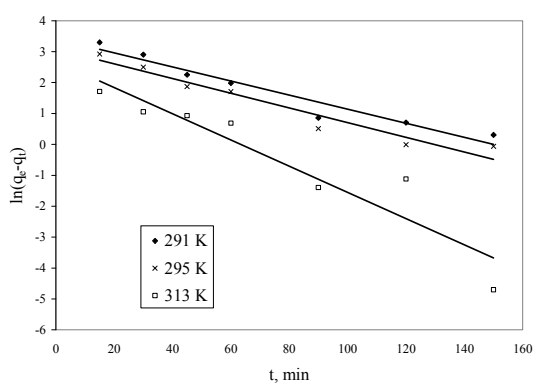

Figure 3: $\quad$ Pseudo-first-order kinetic plot.

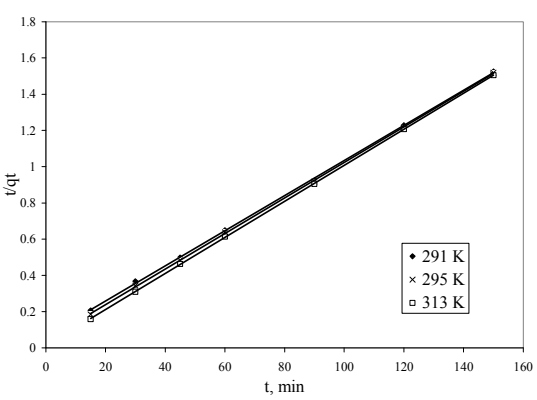

Figure 4: $\quad$ Pseudo-second-order kinetic plot.

The linear form of the pseudo-second-order rate expression of Ho and Mckay, based on the solid phase sorption, is given by:

$$
\frac{\mathrm{t}}{\mathrm{q}_{\mathrm{t}}}=\frac{1}{\mathrm{~h}}+\frac{\mathrm{t}}{\mathrm{q}_{\mathrm{e}}}
$$

where: $\mathrm{h}=\mathrm{k}_{\mathrm{s} 2} \cdot \mathrm{q}_{\mathrm{e}}{ }^{2} ; \mathrm{k}_{2}$ is the pseudo-second-order constant, $\min ^{-1}(\mu \mathrm{g} / \mathrm{g})^{-1}$. Other terms have their usual meanings.

A plot of $\mathrm{t} / \mathrm{q}_{\mathrm{t}}$ versus $\mathrm{t}$ should yield a straight line. From the intercept and slop (figure 4) are calculated the second-order rate constant $\left(\mathrm{k}_{2}\right)$ and the equilibrium adsorption capacity $\left(\mathrm{q}_{\mathrm{e}}\right)$ for all the studied temperatures.

The values of the constants, together with the regression coefficients $\left(\mathrm{R}^{2}\right)$ obtained in both cases are summarized in table 2 .

Table 2: $\quad$ Kinetic parameters for As (III) sorption onto iron oxide.

\begin{tabular}{|c|c|c|c|c|c|c|c|}
\hline Parameter & \multirow{2}{*}{$\begin{array}{c}\mathrm{q}, \text { exp, } \\
\mu \mathrm{g} / \mathrm{g}\end{array}$} & \multicolumn{3}{|c|}{ Pseudo-first-order model } & \multicolumn{3}{|c|}{$\begin{array}{c}\text { Pseudo-second-order } \\
\text { model }\end{array}$} \\
\cline { 4 - 8 } & & $\begin{array}{c}\mathrm{q}_{\mathrm{e}}, \text { calc, } \\
\mu \mathrm{g} / \mathrm{g}\end{array}$ & $\begin{array}{c}\mathrm{k}_{1} \\
\mathrm{~min}^{-1}\end{array}$ & $\mathrm{R}^{2}$ & $\begin{array}{c}\mathrm{q}_{\mathrm{e}}, \text { calc, } \\
\mu \mathrm{g} / \mathrm{g}\end{array}$ & $\begin{array}{c}\mathrm{k}_{2} \\
\mathrm{~min}^{-1}(\mu \mathrm{g} / \mathrm{g})^{-1}\end{array}$ & $\mathrm{R}^{2}$ \\
\hline $291 \mathrm{~K}$ & 98.4 & 30.5 & 0.0228 & 0.9433 & 103 & 0.00144 & 0.9997 \\
\hline $295 \mathrm{~K}$ & 98.8 & 21.8 & 0.0237 & 0.9925 & 102 & 0.00227 & 0.9999 \\
\hline $313 \mathrm{~K}$ & 99.7 & 14.6 & 0.0424 & 0.887 & 100 & 0.00794 & 1 \\
\hline
\end{tabular}

It was observed that correlation coefficient for the pseudo-first-order model was much lower than for the pseudo-second-order rate. Furthermore, the calculated equilibrium sorption capacity for the first order model, at all temperatures, $\mathrm{q}_{\mathrm{e}, \text { calc }}$, values are not close to the experimental values $\mathrm{q}_{\mathrm{e}}$, exp, while, the theoretically predicted equilibrium sorption in the case of the pseudo-secondorder model is close to that determined experimentally, at all temperatures. The pseudo-second-order rate constant $\left(\mathrm{k}_{2}\right)$ increase with increasing temperature on the reactions. This shows that the kinetics of As (III) removal by iron oxide is described by a pseudo-second-order expression instead of a pseudo-first-order. 


\subsection{Thermodynamic studies}

The study of the temperature effect on As (III) removal by iron oxide enabled us to determine the thermodynamic parameters $\left(\Delta \mathrm{G}^{\circ}, \Delta \mathrm{H}^{\circ}\right.$ and $\left.\Delta \mathrm{S}^{\circ}\right)$ by using the following equation:

$$
\ln \mathrm{K}_{\mathrm{d}}=\frac{\Delta S^{\circ}}{R}-\frac{\Delta H^{\circ}}{R T}
$$

where: $\mathrm{R}$ is the ideal gas constant,

$\mathrm{T}$ is the temperature, $\mathrm{K}$

$\mathrm{K}_{\mathrm{d}}$ is the distribution coefficient (amount of removed arsenic per gram of material divided by its concentration in the liquid phase)

The changes in free energy $\left(\Delta \mathrm{G}^{\circ}\right)$ have been calculated using the GibbsHelmholtz relation as:

$$
\Delta \mathrm{G}^{\circ}=\Delta \mathrm{H}^{\circ}-\mathrm{T} \Delta \mathrm{S}^{\circ}
$$

where: the symbols have their usual meanings.

The plot of $\ln K_{d}$ versus $1 / T$ gives a straight line (figure 5) and the obtained thermodynamic parameters are shown in table 3 .

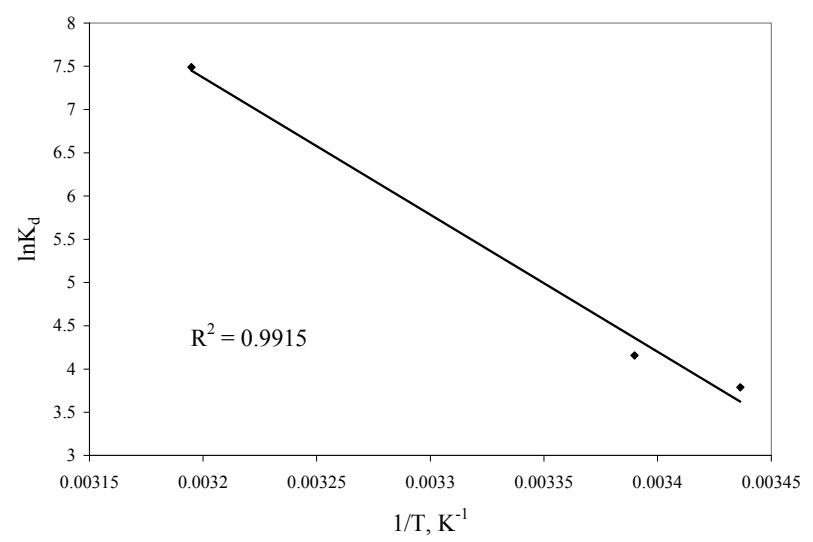

Figure 5: The plot of $\ln \mathrm{K}_{\mathrm{d}}$ versus 1/T for As (III) removal with iron oxide.

Table 3: Thermodynamic parameters evaluated for As (III) sorption on iron oxide.

\begin{tabular}{|c|c|c|c|}
\hline Temperature, $\mathrm{K}$ & $\Delta \mathrm{G}^{\circ}, \mathrm{kJ} / \mathrm{mol}$ & $\Delta \mathrm{H}^{\circ}, \mathrm{kJ} / \mathrm{mol}$ & $\Delta \mathrm{S}^{\circ}, \mathrm{kJ} / \mathrm{mol} \cdot \mathrm{K}$ \\
\hline 291 & -8.79 & \multirow{3}{*}{131.7} & \multirow{2}{*}{0.483} \\
\hline 295 & -10.7 & \multirow{2}{*}{13.7} & \\
\hline 313 & -19.4 & & \\
\hline
\end{tabular}


Results showed the increase in magnitude of $-\Delta G^{\circ}$ with rising temperature of the sorption, which indicate the increase in spontaneity of the sorption with increasing temperature. Based on the $\Delta \mathrm{H}^{\circ}$, it can be conclude that the sorption of As (III) on iron oxide is endothermic $\left(\Delta \mathrm{H}^{\circ}\right.$ positive) and take place with increasing entropy ( $\Delta \mathrm{S}^{\circ}$ positive). This suggests the increase in number of species during sorption process at the solid-liquid interface when hydrated solutes are sorbed by the solid phase.

\subsection{Adsorption isotherms}

The adsorption isotherm of As (III) is presented in figure 6.

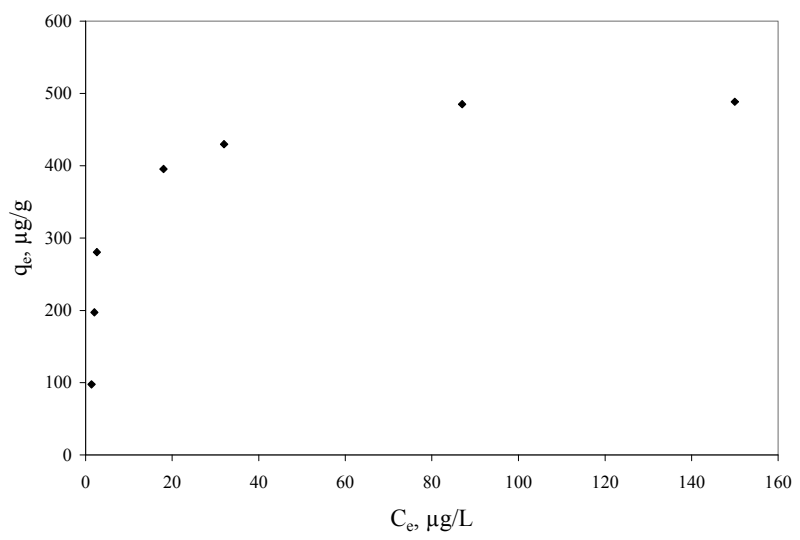

Figure 6: The adsorption isotherm of As (III).

The adsorption capacity increased with increasing equilibrium concentration of arsenic. Then, they approached a constant value at the high equilibrium concentration. The maximum adsorption capacity of iron oxide determined experimental is $490 \mu \mathrm{g} / \mathrm{g}$.

Several models have been published in the literature to describe experimental data of adsorption isotherms. The Langmuir and Freundlich models are the most frequently employed models. In this work, both models were used to describe the relationship between the amount of As (III) ions adsorbed by iron oxide and its equilibrium concentration in solution for 90 minutes at the temperature of $295 \mathrm{~K}$.

The linear form of the Freundlich isotherm equation can be written as:

$$
\ln \mathrm{q}_{\mathrm{e}}=\ln \mathrm{K}_{\mathrm{F}}+\frac{1}{\mathrm{n}} \ln \mathrm{C}_{\mathrm{e}}
$$

and the Langmuir isotherm as the following equation:

$$
\frac{\mathrm{C}_{\mathrm{e}}}{\mathrm{q}_{\mathrm{e}}}=\frac{1}{\mathrm{~K}_{\mathrm{L}} \mathrm{q}_{\mathrm{m}}}+\frac{\mathrm{C}_{\mathrm{e}}}{\mathrm{q}_{\mathrm{m}}}
$$


where: $\mathrm{q}_{\mathrm{e}}$ is the amount of arsenic adsorbed per gram of sorbent, $\mu \mathrm{g} / \mathrm{g}$;

$\mathrm{C}_{\mathrm{e}}$ is the equilibrium concentration of arsenic, $\mu \mathrm{g} / \mathrm{L}$;

$\mathrm{K}_{\mathrm{f}}$ and $1 / \mathrm{n}$ are characteristic constants that can be related to the relative adsorption capacity of the adsorbent and the intensity of adsorption, respectively;

$\mathrm{q}_{\mathrm{m}}$ is a measure of monolayer adsorption capacity $[\mu \mathrm{g} / \mathrm{g}]$ and $\mathrm{K}_{\mathrm{L}}$ is a constant related to the free energy of adsorption.

The curves and parameters, as well as the correlation coefficients $\left(\mathrm{R}^{2}\right)$, for As (III) removal trough adsorption onto iron oxide are presented in figures 7,8 and table 4.

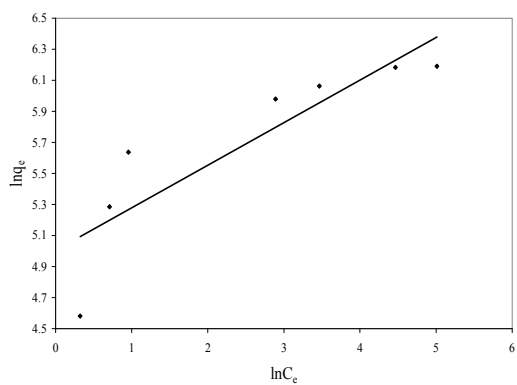

Figure 7: Freundlich plot of As (III) adsorption on iron oxide.

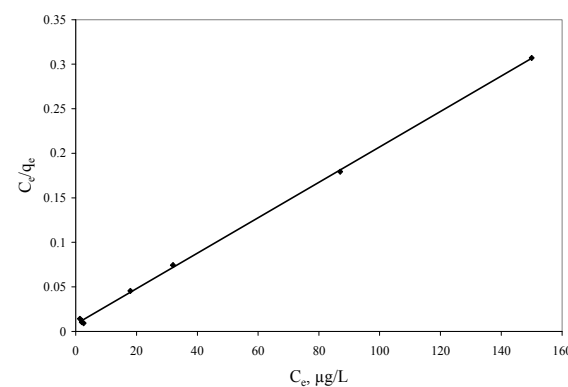

Figure 8: Langmuir plot of As (III) adsorption on iron oxide.

Table 4: $\quad$ Parameters of different isotherm for the As (III) adsorption on iron oxide.

\begin{tabular}{|c|c|c|c|c|c|}
\hline \multicolumn{3}{|c|}{ Freundlich isotherm } & \multicolumn{3}{c|}{ Langmuir isotherm } \\
\hline $\mathrm{K}_{\mathrm{F}}, \mu \mathrm{g} / \mathrm{g}$ & $1 / \mathrm{n}$ & $\mathrm{R}^{2}$ & $\mathrm{~K}_{\mathrm{L}}, \mathrm{L} / \mu \mathrm{g}$ & $\mathrm{q}_{\mathrm{m}}, \mu \mathrm{g} / \mathrm{g}$ & $\mathrm{R}^{2}$ \\
\hline 149 & 0.2744 & 0.7689 & 0.247 & 500 & 0.9994 \\
\hline
\end{tabular}

The Freundlich plot has a correlation coefficient very low; this suggests a restriction on the use of Freundlich isotherms. The numerical value of $1 / \mathrm{n}<1$, which provides information about surface heterogeneity and surface affinity for the solute, indicates a favourable sorption of As (III) and a very high affinity of the iron oxide for As (III).

The Langmuir model effectively describes the sorption data with a correlation coefficient of 0.9994 . Thus the isotherm follows the sorption process in the entire concentration range studied. Furthermore, the maximum adsorption capacity obtained from the Langmuir plot is almost the same with the maximum adsorption capacity obtained experimentally.

The dimensional constant, called separation factor $\left(\mathrm{R}_{\mathrm{L}}\right)$, was used to describe the essential characteristics of Langmuir isotherm $\left(R_{L}>1\right.$, unfavourable; $R_{L}=1$, linear; $0<\mathrm{R}_{\mathrm{L}}<1$, favorable; and $\mathrm{R}_{\mathrm{L}}=0$, irreversible), 


$$
\mathrm{R}_{\mathrm{L}}=\frac{1}{1+\mathrm{K}_{\mathrm{L}} \cdot \mathrm{C}_{0}}
$$

In fact, the separation factor is a measure of the adsorbent capacity used. $R_{L}$ values were calculated for the entire concentration range studied and found to be greater than 0 and less than 1 , showing favourable adsorption.

\section{Conclusions}

The sorption performance of a synthetic iron oxide for the removal of As (III) removal was evaluated. The $\mathrm{pH}_{\mathrm{pzc}}$ of the iron oxide was found to be 6.1, close to the neutral $\mathrm{pH}$.

A detailed laboratory study was conducted to evaluate the impact of temperature during the adsorption of arsenic by the synthetic iron oxide obtained from the annealing of the iron oxalate at $550^{\circ} \mathrm{C}$.

The initial rate of adsorption is fast, followed by a slower rate that gradually approaches a plateau. The equilibrium is reached in 90 minutes for all the studied temperatures. Adsorption rate data are best described by a pseudo-second-order kinetic model.

Temperature dependence of sorption reveals the increase in sorption performance of the sorbent with temperature. The values of Gibbs free energy $\left(\Delta \mathrm{G}^{\circ}\right)$ show the spontaneous nature of arsenite sorption and the positive values of the standard enthalpy $\left(\Delta \mathrm{H}^{\circ}\right)$ show the endothermic nature of arsenite sorption on iron oxide. Positive entropy $\left(\Delta \mathrm{S}^{\circ}\right)$ suggest the affinity of iron oxide for the arsenite in solution.

The equilibrium sorption data were modelled using Freundlich and Langmuir isotherms. Comparisons of the correlation coefficient demonstrate that the sorption process is best described by the Langmuir model. The dimensional separation factor used to predict the essential characteristics of Langmuir isotherm indicated favourable sorption in the entire range concentration. The maximum adsorption capacity of iron oxide, in the process of arsenite removal from water, determined experimentally and also predicted from the Langmuir isotherm is $500 \mu \mathrm{g} / \mathrm{g}$.

\section{Acknowledgements}

The authors gratefully acknowledge the financial support provided by the UEFISCSU, under grant no. 694/19.01.2009, Code 927, "Integrated concept about depollution of waters with arsenic content, through adsorption on oxide materials, followed by immobilization of the resulted waste in crystalline matrices". 


\section{References}

[1] Streat, M., Hellgardt, K., Newton \& N.L.R., Hydrous ferric oxide as an adsorbent in water treatment. Part 2. Adsorption studies, Process Safety and Environmental Protection, 86, pp. 11-20, 2008.

[2] Jonsson, J. \& Sherman, D.M., Sorption of As (III) and As(V) to siderite, green rust (fougerite) and magnetite; Implications for arsenic release in anoxic groundwaters, Chemical Geology, 255, pp. 173-181, 2008.

[3] Mamindy-Pajany, Y., Hurel, C., Marmier, N. \& Romeo, M., Arsenic adsorption onto hematite and goethite, Comptes Rendys Chimie, 12(8), pp. 876-881, 2009.

[4] Hartley, W. \& Lepp, N.W., Remediation of arsenic contaminated soils by iron-oxide application, evaluated in terms of plant productivity arsenic and phytotoxic metal uptake, Science of the Total Environment, 390, pp. 35-44, 2008.

[5] Borah, D., Satokawa, S., Kato, S. \& Kojima, T., Sorption of As(V) from aqueous solution using acid modified carbon black, Journal of Hazardous Materials, 162, pp. 1269-1277, 2009.

[6] Camacho, J., Wee, H.Y., Kramer, T.A. \& Autenrieth, R., Arsenic stabilization on water treatment residuals by calcium addition, Journal of Hazardous Materials, 165, pp. 599-603, 2009.

[7] Chen, Y.N., Chai, L.Y. \& Shu, Y.D., Study of arsenic(V) adsorption on bone char from aqueous solution, Journal of Hazardous Materials, 160, pp. 168-172, 2008.

[8] Nguyen, V.T., Vigneswaran, S., Ngo, H.H., Shon, H.K. \& Kandasamy, J., Arsenic removal by a membrane hybrid filtration system, Desalination, 236, pp. 363-369, 2009.

[9] So, H.U., Postma, D., Jakobsen, R. \& Larsen, F., Sorption and desorption of arsenate and arsenite on calcite, Geochimica et Cosmochimica Acta, 72, pp. 5871-5884, 2008.

[10] Jeong, Y., Fan, M., Singh, S., Chuang, C.L., Saha, B. \& van Leeuwen, J.H., Evaluation of iron oxide and aluminium oxide as potential arsenic(V) adsorbents, Chemical Engineering and Processing, 46, pp. 1030-1039, 2007.

[11] Zeng, L., A method for preparing silica-containing iron(III) oxide adsorbents for arsenic removal, Water Research, 37, pp. 4351-4358, 2003.

[12] Thirunavukkarasu, O. S., Viraraghavan, T. \& Subramanian, K.S., Arsenic removal from drinking water using granular ferric hydroxide, Water $S A, 29$, pp. 161-170, 2003.

[13] Gupta, K. \& Ghosh, U.C., Arsenic removal using hydrous nanostructure iron(III)-titanium(IV) binary mixed oxide from aqueous solution, Journal of Hazardous Materials, 161, pp. 884-892, 2009.

[14] Banerjee, K., Amy, G.L., Prevost, M., Nour, S., Jekel, M., Gallagher, P.M. $\&$ Blumenschein, C.D., Kinetic and thermodynamic aspects of adsorption of arsenic onto granular ferric hydroxide (GFH), Water Research, 42, pp. 3371-3378, 2008. 
[15] Chutia, P., Kato, S., Kojima, T. \& Satokawa, S., Adsorption of As(V) on surfactant-modified natural zeolites, Journal of Hazardous Materials, 162, pp. 204-211, 2009.

[16] Mondal, P., Majumder, C.B. \& Mohanty, B., Effects of adsorbent dose, its particle size and initial arsenic concentration on the removal of arsenic, iron and manganese from simulated ground water by $\mathrm{Fe}^{3+}$ impregnated activated carbon, Journal of Hazardous Materials, 150, pp. 695-702, 2008.

[17] Partey, F., Norman, D., Ndur, S. \& Nartey, R., Arsenic sorption onto laterite iron concretions: Temperature effect, Journal of Colloid and Interface Science, 321, pp. 493-500, 2008.

[18] Pedersen, H.D., Postma, D. \& Jakobsen, R., Release of arsenic associated with the reduction and transformation of iron oxides, Geochimica et Cosmochimica Acta, 70, pp. 4116-4129, 2006.

[19] Ohe, K., Tagai, Y., Nakamura, S., Oshima, T. \& Baba, Y., Adsorption behaviour of arsenic(III) and $\operatorname{arsenic}(\mathrm{V})$ using magnetite, Journal of Chemical Engineering of Japan, 38, pp. 671-676, 2005.

[20] Hsu, J.C., Lin, C.J., Liao, C.H. \& Chen, S.T., Removal of As(V) and As (III) by reclaimed iron-oxide coated sands Journal of Hazardous Materials, 153, pp. 817-826, 2008.

[21] Cerovic, Lj. S., Milonjic, S.K., Todorovic, M.B., Trtanj, M.I., Pogozhev, Y.S., Blagoveschenskii, Y. \& Levashov, E.A., Point of zero charge of different carbides, Colloids and Surfaces A: Physicochem. Eng. Aspects, 297, pp. 1-6, 2007. 